\title{
FGFR Inhibitor AZD4547
}

National Cancer Institute

\section{Source}

National Cancer Institute. FGFR Inhibitor AZD4547. NCI Thesaurus. Code C88272.

An orally bioavailable inhibitor of the fibroblast growth factor receptor (FGFR) with potential antineoplastic activity. FGFR inhibitor AZD4547 binds to and inhibits FGFR, which may result in the inhibition of FGFR-related signal transduction pathways, and, so, the inhibition of tumor cell proliferation and tumor cell death. FGFR, up-regulated in many tumor cell types, is a receptor tyrosine kinase essential to tumor cellular proliferation, differentiation and survival. 